\title{
"Fair to me, fair to us, or fair to you?" Unresolved conflict between government and graduates over Australia's tertiary education loans
}

\section{Valerie Braithwaite, Eliza Ahmed \& Deborah Cleland}

To cite this article: Valerie Braithwaite , Eliza Ahmed \& Deborah Cleland (2020): "Fair to me, fair to us, or fair to you?" Unresolved conflict between government and graduates over Australia's tertiary education loans, Journal of Economic Policy Reform, DOI: 10.1080/17487870.2020.1785298

To link to this article: https://doi.org/10.1080/17487870.2020.1785298

Published online: 13 Jul 2020.

Submit your article to this journal $\square$

Џ Article views: 51

Q View related articles ¿

View Crossmark data $־$

Citing articles: 1 View citing articles \ulcorner 


\title{
"Fair to me, fair to us, or fair to you?" Unresolved conflict between government and graduates over Australia's tertiary education loans
}

\author{
Valerie Braithwaite, Eliza Ahmed and Deborah Cleland (ID
}

School of Regulation and Global Governance (RegNet), Australian National University College of Asia and the Pacific, Canberra, Australia

\begin{abstract}
Australia adopted income-contingent government loans for tertiary students 30 years ago, aiming to promote greater access and equity in higher education, as repayments were required only when income exceeded a threshold. Why then does the scheme still cause dissension and with what consequences for government? We analyse qualitative and quantitative survey data to answer this question. Contrary to the government's universal conception of fairness, graduates keenly perceive unfairness relative to their peers. Our results indicate that perceptions of unfair treatment create enduring difficulties for governments in securing cooperation from their citizens.
\end{abstract}

\section{ARTICLE HISTORY}

Received 30 January 2019

Accepted 2 March 2020

\section{KEYWORDS}

Higher education loans; income contingent loans; justice; fairness; public policy

\section{Policy Highlights}

- policies that are perceived as unfair by citizens can provoke defiance and noncompliance over long periods

- citizens tend to evaluate fairness with reference to their peers, rather than with the macro-economic lens of governments

- reconciling these two perspectives to create both fair policy and willing cooperation requires dialogue and compromise

\section{Introduction}

Apparently, well-designed policy can have unanticipated consequences when the needs of those affected by the policy are not well understood by government (Clifton, DíazFuentes, and Fernández-Gutiérrez 2017; Clifton, Fernández-Gutiérrez, and García-Olalla 2017). The aim of this article is to consider one such case, Australia's income-contingent loan programme for tertiary students, and ask how and why a scheme that was designed to increase equity has created unresolved conflict over decades. We show that enduring resentments can prevail if government fails to engage and provide a credible narrative around a policy's benefits and fairness. 
Income-contingent loans in Australia allow university students to defer tuition payment until their income exceeds a threshold. Thirty years ago, Australia was an early adopter of income-contingent loans for university students. Income-contingent loans were soon adopted in the UK and New Zealand and have been hailed internationally as a successful exemplar of a user-pays system for tertiary education (Chapman 2006; Britton, van der Erve, and Higgins 2019).

The Australian programme was introduced in 1989 as HECS, the Higher Education Contribution Scheme. The impetus for introducing the scheme was to shift part of the cost of higher education from the Australian Government to students. ${ }^{1}$ Between 1974 and 1989, students who qualified for entry could attend university in Australia without paying tuition fees. As more students took advantage of the opportunity and costs mounted, "free" university education was regarded by both major political parties as unsustainable. The Wran Report produced by the Committee on Higher Education Funding (1988) reviewed a range of options for how funding contributions might be made by beneficiaries, namely students, graduates, their parents and employers. The result was the Higher Education Funding Act 1988, which initially eschewed complicated funding proposals and legislated a simple contribution of AU\$1800 from students (Jackson 2003a). The contribution could be deferred until income reached the compulsory threshold for repayment. If payment was made upfront, debtors received a discount of $15 \%$.

The Higher Education Funding Act 1988 (Australian Government 2016) made clear the policymakers' intentions: A higher education system that was "characterised by quality, diversity, and equity of access" and was "appropriate to meet Australia's social and economic needs for a more highly educated and skilled population".

The appeal of the scheme was that it enabled talented students from low socioeconomic backgrounds to attend university in circumstances where they might not have the money to pay university fees. There was concern that the reintroduction of fees might deter students and undermine the policy intent of expanding opportunities to lift skill levels nationally. As a result, attention has focused on tracking participation (Chapman 2006; Jackson 2003a; James et al. 2007).

While income-contingent loans were offered to promote equity, shortcomings have been observed (Belfield et al. 2017; Birch and Miller 2006). Implementation of the policy has involved many modifications, not all considered fair and reasonable (eg Barr 2012; Birch and Miller 2006; Senate Education and Employment Legislation Committee 2014, 2017). The scheme has also had unanticipated problems such as failures to repay debt (Ey 2017) and links with tax avoidance and evasion (Ahmed and Braithwaite 2004; Highfield and Warren 2015; see Chapman and Leigh 2009 for a contrary view). The gap between government expectations and graduate commitment to the policy appears significant, even after 30 years.

This article claims that this gap can be explained through different lenses of fairness. Policymakers assess equity in terms of opportunity for higher education, employment prospects, income, career success, marriage and family. These indicators are "objective milestones". Fairness means that those with a HECS debt are not disadvantaged on these indicators compared to others.

Objective indicators, however, do not capture the full meaning of fairness in the experience of students. Students assess the benefits and fairness of policy subjectively 
in terms of perceptions of disadvantage in their social group. Perceptions of disadvantage are known factors that undermine cooperation and trust in authorities (Tyler and Blader 2000).

We explore this gap in fairness perceptions in the following six sections. Part 2 provides details about the operation of income-contingent loans in Australia and the controversy over benefits and fairness. Part 3 introduces the theoretical regulatory compliance model guiding this research, the Wheel of Social Alignments. The Wheel accommodates objective indicators of equity in policy design as well as subjective indicators experienced by those "living" with the policy (Braithwaite 2017). Part 4 describes the survey method. In Part 5 we show that those who deferred payment of their tuition were more aggrieved and less cooperative than those who paid fees upfront, and we delve into the qualitative data to discover what gives rise to and sustains this grievance. In Part 6 we reflect on our findings that fairness is both objective and subjective and is seen differently depending on the perspective we take. Conclusions are presented in Part 7.

\section{Income-contingent loans in Australian higher education}

\subsection{How HECS works}

Australia's HECS continues today under different monikers. ${ }^{2}$ Domestic students can opt for an income-contingent loan to avoid up-front fees if they qualify for a governmentsupported place. All universities, and a select group of other higher education and vocational education providers, ${ }^{3}$ have government-supported places.

Students repay their government loan through the Australian Taxation Office (ATO) when their income exceeds a threshold. Employees tell their employer they have a debt, and repayments are deducted with other taxes. The self-employed are responsible for making their own repayments. Debtors can also make voluntary repayments above those required by law. Compulsory repayments increase with income, to a maximum of $10 \%$. Currently, the repayment threshold is $\mathrm{AU} \$ 45,881$, although thresholds and rates regularly change. The debt is not subject to interest but is adjusted annually using the Consumer Price Index. The ATO issues information on repayment levels and rates and administers the programme. ${ }^{4}$

The consistent messaging around these loans has been that those with a university education are privileged in the labour market in terms of the kinds of jobs they do and the remuneration they receive (Jackson 2003a). Therefore, it is not fair for ordinary taxpayers to fully subsidize them. At the same time, the Australian Government has consistently pronounced that making tertiary education widely accessible is in the national interest: "Higher education is integral to the long-term success of Australia's intellectual and economic development." 5

While messaging has been stable, each federal budget throughout the 1990s proposed changes to the scheme (Birch and Miller 2006; Jackson 2003a) - some rejected, some accepted and some retracted at a later date. One contested change within the first decade was that course costs were differentiated, most notably making professional courses more expensive than arts courses. Another significant change from an equity perspective was phasing out discounts for paying fees upfront and for voluntary repayments (Doyle 2013). ${ }^{6}$ Discounts were abolished, saving money and addressing criticisms that they were unfair. 
In 2003-4, major changes were again proposed, and again met with student resistance (Jackson 2003b). Most recently, in 2017, divisions became visible in a Senate inquiry into proposed reforms, when Committee members could not agree on a final report, and members of the major and minor opposition parties lodged dissenting reports, amid student protests.

\subsection{The controversy around HECS}

The key plank for opposition is historical. The 1966 UN International Covenant on Economic, Social and Cultural Rights states that "higher education shall be made equally accessible to all, on the basis of capacity, by every appropriate means, and in particular by the progressive introduction of free education" (Article 13). The idea of higher education as a human right has remained salient, even though many governments have retreated from the idea, arguing that individuals who do better in life because of their education should contribute to the costs of that education (Wran Report 1988; Barr 2012). How the cost of tertiary education should be shared between students and government, therefore, is likely to be a vexed question as governments continue to make adjustments to higher education funding and students and communities push back.

Changes to loan conditions routinely re-ignite furore over fairness and the impact of changes on less advantaged students (Birch and Miller 2006). Financial sacrifice among poorer students with a HECS debt is a recurring theme, as is constraint on students' choice and participation in university life, reports of student poverty and the distraction of increased paid outside work while studying (Birch and Miller 2006; James et al. 2007; Senate Education and Employment Legislation Committee 2014).

While discontent continues, Marks (2009) has tracked large student cohorts and concluded that there are no traces of disadvantage resulting from the loans programme, at least none up to the 2005 reforms. He found that those with a university education debt were not doing worse than those without a debt in terms of finding a job, starting a family and buying a house.

However, what if the income-contingent loan programme is a success in so far as it gives disadvantaged groups the opportunity to attend university, but fares poorly in so far as it does not alleviate feelings of disadvantage? What if carrying a HECS debt feels like an unfair burden?

\section{The wheel of social alignments}

The Wheel of Social Alignments is a conceptual model that illustrates how perceptions of justice, benefits and moral obligations interact with objective design features of policy to influence regulatory compliance (Braithwaite 2017). Cooperation with authorities is likely to increase when citizens: (1) believe that policy, law and administration are yielding benefits for self or society; (2) perceive fairness in the system both in terms of procedures and outcomes for self and others; and (3) perceive integrity in the system such that they feel morally obliged to cooperate and obey the law. When the personal and shared narratives combine all three elements, citizens are more likely to defer to government and its decisions. The wheel then turns, and the momentum carries cooperation forward, even in the face of disruptive policy changes (Braithwaite 2017). Should public 
opposition grow to the point where defiance sets in and the wheel stops, a reset is required, a relational reset that restores public confidence and cooperation. Central to the reset is respectful engagement around the benefits, fairness and integrity of the policy and responsive changes to its design.

The interplay between macro-policy parameters and micro perceptions is key to understanding how this model sheds light on the continuous dissension in higher education policy in Australia. In the case of income-contingent loans, the resets have been regular, without gaining the momentum needed to win enduring public acceptance. Could it be that opposition has stemmed from students and graduates' failure to see benefits from the loans, a perception of unfairness in the design and administration of the scheme, and questioning of the legitimacy of the scheme to the point of defiance? More specifically, do those who have an income-contingent loan (the supposed beneficiaries) express greater opposition on grounds of low benefit, unfairness and defiance than those who have paid their fees upfront?

\section{Method}

In 2000 Australian National University researchers from the Centre for Tax System Integrity sent the Graduates' Hopes, Visions and Actions (GHVA) Survey via mail to a sample of Australian graduates whose degrees were conferred between 1989 and 1999 in the Australian Capital Territory (Ahmed 2005). ${ }^{7}$ The random sample was drawn from the two universities based in the Territory and was stratified in terms of course of study. Of the 1500 questionnaires posted, 447 were returned after several reminders, giving a response rate of $33 \%$ (after excluding undelivered questionnaires).

Survey questions encompassed attitudes to the tax system and income-contingent loans, university experience and social-demographic background. Attitude scales to measure benefits, fairness and moral obligation were formed from individual questions answered on Likert rating scales.

In addition, a comparative qualitative analysis was carried out on answers to three open-response questions at the end of the survey, asking how the income-contingent loan scheme (HECS was in operation at the time) could be improved, its fairness and effectiveness.

Survey respondents' mean age was 31.39 years $(\mathrm{SD}=9.84)$, with gender relatively evenly divided (41\% male, 59\% female). Respondents mainly studied full-time (71\%) rather than part-time (29\%). The distribution of respondents' personal income was (a) less than 20,000 AUD (8.7\%); (b) 20,001-30,000 AUD (9.7\%); (c) 30,001 AUD - 50,000 AUD (55.8\%); (d) 50,001 AUD - 75,000 AUD (20.3\%); (e) 75,001 AUD - 100,000 AUD (3.4\%); and (f) more than 100,000 AUD (2.2\%). To reduce skewness in the scale, two response categories (“75,001 - 100,000 AUD” and “more than 100,000 AUD”) were collapsed into one category.

\subsection{Measuring HECS debt}

Debt status was assessed using a single item: "Do you have a HECS debt?", scored 1 for yes (65\%) and 0 for no (35\%). Most of those without a debt would have paid fees upfront, although some would have used a mixed payment option, making voluntary payments 
part-way or after they completed their courses. Those who had paid fees upfront mainly financed themselves $(65 \%)$ with a further $25 \%$ relying on parents and $10 \%$ on employers.

\subsection{Attitude scales to HECS}

The value of HECS (benefits and fairness) scale comprised nine items: (a) HECS is functioning very well as it is; (b) In general, HECS is a fair system; (c) HECS favors the rich over the poor; (d) HECS should be abolished; (e) People are not satisfied with HECS; (f) People are very resentful about repaying a HECS debt; (g) There are more negatives than positives in HECS; (h) When I think about repaying a HECS debt, I feel as if I am losing out; and (i) In general, I don't think of the benefits - I just see HECS as taking money from my pocket. Each item had six response categories: $1=$ strongly disagree, 2 = disagree, 3 = slightly disagree, $4=$ slightly agree, 5 = agree, $6=$ strongly agree . Responses were reverse scored for all but the first two items so that a high score meant the respondent held a positive attitude and saw value in HECS. Factor analysis and an alpha reliability coefficient of 94 confirmed the scale's internal consistency. Scores were averaged over the nine items for each respondent so that scale scores ranged from 1 (seeing low value in HECS) to 6 (seeing high value in HECS).

The educational benefit scale represented the degree to which respondents believed they had obtained something of value in return for their HECS payment. It comprised 13 items: (a) The skills I achieved during this course are now useless (reverse coded); (b) The course helped me to grow professionally; (c) The course helped me to get the best kind of job easily; (d) The course facilitated my employment level; (e) The course helped me to relate knowledge with practice; (f) It was often hard to discover what was expected of me in this course (reverse coded); (g) It was always easy to know the standard of work expected; (h) My lecturers were extremely good at explaining things; (i) The teaching staff of this course motivated me to do my best work; ( $j$ ) The staff put a lot of time into commenting on my work; (k) The teaching staff normally gave me helpful feedback on how I was going; (l) The course helped me develop a well-defined career goal; and (m) The course brought a sense of achievement. Responses once again were made on a rating scale from strongly disagree (1) to strongly agree (6). Responses were scored so that a high score reflected how positively the respondent viewed the personal educational benefit of a degree. Factor analysis and the alpha reliability coefficient of .87 confirmed scale internal consistency. Responses were averaged so that scale scores ranged from 1 (no educational benefit) to 6 (high educational benefit).

The scale measuring unfairness of HECS rules comprised three items: (a) Students who pay upfront are eligible to have a $25 \%$ discount rate - this is unfair; (b) Differential rates of HECS apply to commencing students depending upon the type of course (e.g. medicine, science) undertaken - this is unfair; (c) Recently the threshold level for compulsory payment of a HECS debt was lowered - this is unfair. The alpha reliability coefficient for this scale of .65 was lower than other scales, but satisfactory given the small number of items. Responses from strongly disagree (1) to strongly agree (6) were averaged to produce a scale score ranging from 1 to 6 where higher scores reflected stronger endorsement of the unfairness of HECS rules.

Responsibility to pay HECS provided the first measure of moral obligation. Respondents rated these items from strongly disagree (1) to strongly agree (6): (a) One should repay the HECS debt and share in the cost of providing education; (b) It's 
disappointing that some graduates do not repay their HECS debt; and (c) Graduates who do not repay their HECS debt spoil things for future students. The items were highly intercorrelated producing an alpha reliability coefficient of .86. Responses to the three items were averaged and ranged from 1 to 6 with higher scores reflecting greater responsibility to pay HECS.

Moral obligation to comply with HECS reporting requirements is also reflected in fear of deterrence and feelings of shame if caught. Perceived deterrence was measured by combining responses to questions about (a) the probability of being caught (rating scale from 1 to 5), (b) the probability of receiving sanctions (rating scale from 1 to 5), and (c) the probability of seriousness of the consequences (rating scale from 1-4) (see Braithwaite and Makkai 1991) in the following scenario:

"Imagine that you chose to defer payment of your HECS debt and you are now required to repay the debt through the taxation system. You DO NOT repay the debt"

Each respondent received a deterrence score calculated by multiplying (a), (b) and $(c)$.

In the above scenario, respondents were asked to imagine that they had been caught for not repaying their HECS debt. They were then asked: "Assume that you now have to pay a substantial fine or penalty. How likely is it that the following would occur?" Responses of $1=$ not likely, $2=$ may happen, $3=$ likely, $4=$ almost certain were made to the following 11 items: (a) feel that I had let down my family; (b) feel ashamed of myself; (c) feel angry with myself for what I did; (d) feel concerned to put matters right and put it behind me; (e) feel that what I had done was wrong; (f) feel bad about the trouble I'd caused; (g) feel humiliated; (h) feel that I have harmed my reputation; (i) feel embarrassed; (j) feel guilty; (k) regret the mistakes I have made (see Ahmed and Braithwaite 2005 for more details). Factor analysis and an alpha reliability coefficient of .95 confirmed scale internal consistency. Averaging item ratings yielded scores ranging from 1 to 4 with higher scores indicating greater likelihood of feeling shame.

\subsection{Plan of analysis}

The purpose of the analysis was to compare those carrying a HECS debt with those who did not have a HECS debt on the six scales representing attitudes and beliefs about HECS - the benefits of HECS, the fairness of the scheme and the moral obligation to comply with the rules. First, independent t-tests were conducted to compare the mean scores for HECS debt and HECS no-debt groups on each of the six scales.

Interpreting these findings, however, is not straightforward. The groups are not matched as they would be in an experimental context. They are "natural" groups and as such vary on other variables, in particular, the social-demographic variables of age, sex, full-time (versus part-time) study and personal income. These variables have been significant predictors of HECS use and attitudes in previous research (Ahmed and Braithwaite 2004, 2005).

For this reason, a second set of analyses was conducted. Point-biserial correlation coefficients were calculated between HECS debt (versus no-debt) and each attitude scale, with and without controlling for the social-demographic variables. In all but 
one case, no changes occurred as a result of introducing social-demographic controls.

On four of the six belief and attitude scales, findings supported the thesis that having a HECS debt in and of itself is associated with negativity around HECS.

The next step was to explicate more fully the sources of negativity, given that one of the scales that did not produce a significant difference between the debt and no-debt groups was the scale measuring the value of HECS overall. Particular narratives around HECS seemed likely to be important. To this end, an analysis of the qualitative responses to HECS policy was undertaken.

\section{Results}

\section{1 ...Quantitative data}

The results for the independent t-tests comparing the HECS debt and no-debt groups on attitudes and beliefs appear in Table 1. The means for scales measuring overall value of HECS, educational benefit, and responsibility to pay HECS are consistently above the scale midpoint of 3.5 (neither agree nor disagree), suggesting that the sample overall was inclined to be positive about HECS.

For the scale measuring overall value of HECS, no statistically significant difference was found between the debt and no-debt groups $(\mathrm{M}=3.55$ and $\mathrm{M}=3.70$, respectively, see Table 1).

For the educational benefit scale in Table 1, the HECS debt group was significantly less positive than the no-debt group ( $\mathrm{M}=3.84$ and $\mathrm{M}=4.09$, respectively). The HECS debt group also felt significantly less responsible to pay HECS than the no-debt group ( $\mathrm{M}=3.90$ and $\mathrm{M}=4.34$, respectively).

The mean scores in Table 1 for HECS rules being unfair showed the debt group tending to agree that they were unfair while the no-debt group tended to disagree $(\mathrm{M}=3.99$ and $\mathrm{M}=3.23$, respectively). The difference between the groups was statistically significant.

Table 1. Attitude and belief means (standard deviations) for the total sample, HECS debt and no-debt groups with t-statistics comparing HECS debt and no-debt groups.

\begin{tabular}{|c|c|c|c|c|}
\hline Attitude or belief & $\begin{array}{c}\text { Mean (SD) } \\
\text { Total } \\
\mathrm{n}=426^{\mathrm{a}}\end{array}$ & $\begin{array}{c}\text { Mean (SD) } \\
\text { Debt } \\
\mathrm{N}=276^{\mathrm{a}}\end{array}$ & $\begin{array}{c}\text { Mean (SD) } \\
\text { No-debt } \\
\mathrm{N}=150^{\mathrm{a}}\end{array}$ & $t$-statistic \\
\hline $\begin{array}{l}\text { Value of HECS } \\
\text { (scored } 1 \text { to } 6 \text { ) }\end{array}$ & $3.60(1.21)$ & $3.55(1.23)$ & $3.70(1.16)$ & 1.24 \\
\hline Educational benefit (scored 1 to 6 ) & $3.93(.78)$ & $3.84(.81)$ & $4.09(.71)$ & $3.20^{* * *}$ \\
\hline $\begin{array}{l}\text { Unfairness of HECS rules } \\
\text { (scored } 1 \text { to } 6 \text { ) }\end{array}$ & $3.72(1.24)$ & $3.99(1.20)$ & $3.23(1.18)$ & $-6.40^{* * *}$ \\
\hline $\begin{array}{l}\text { Responsibility to pay } \\
\text { (scored } 1 \text { to } 6 \text { ) }\end{array}$ & $4.06(1.21)$ & $3.90(1.25)$ & $4.34(1.08)$ & $3.66^{* * *}$ \\
\hline $\begin{array}{l}\text { Perceived deterrence } \\
\quad \text { (scored } 1 \text { to 100) }\end{array}$ & $56.92(28.34)$ & $59.20(28.15)$ & $52.73(28.32)$ & $-2.26^{*}$ \\
\hline $\begin{array}{l}\text { Feeling shame } \\
\text { (scored } 1 \text { to } 4)\end{array}$ & $2.54(.89)$ & $2.47(.89)$ & $2.65(.88)$ & $2.02 *$ \\
\hline
\end{tabular}

Source: Authors. Note: The higher the score the stronger the endorsement of the attitude or belief.

${ }^{a}$ This is the minimum sample size with missing values accounting for fluctuation in the size of the group for the independent t-test.

${ }^{*} p<.05,{ }^{* * *} p<.001$ 
Table 2. Bivariate and partial correlations (controlling for gender, age, income and being a full-time student) of the attitude and belief scales with having (scored 1$)$ or not having (scored 0$)$ a HECS debt $(n=377)$.

\begin{tabular}{lll}
\hline & \multicolumn{1}{c}{ Debt } & Debt \\
Attitude or belief & Bivariate correlation & Partial correlation \\
\hline Value of HECS & -.06 & -.09 \\
Educational benefit & $-.15^{* * *}$ & -.07 \\
Unfairness of HECS rules & $.29^{* * *}$ & $-26^{* * *}$ \\
Responsibility to pay & $-.17^{* * *}$ & $-.18^{* * *}$ \\
Perceived deterrence & $.11^{*}$ & $-13^{* *}$ \\
Feeling shame & $-.10^{*}$ & $-.11^{*}$ \\
\hline
\end{tabular}

${ }^{*} p<.05,{ }^{* *} p<.01,{ }^{* * *} p<.001$

All groups considered it less than likely that they would feel ashamed if caught for not paying their HECS debt, with the debt group rejecting a shame response significantly more than the no-debt group ( $\mathrm{M}=2.47$ and $\mathrm{M}=2.65$, respectively, see Table 1$)$.

On the deterrence measure, the debt group expressed significantly greater fear of deterrence (of being caught and punished in a scenario setting) than the no-debt group $(\mathrm{M}=59.20$ and $\mathrm{M}=52.73$, respectively, see Table 1$)$.

The results in Table 2 show the changes that occur after introducing statistical controls for gender, age, personal income and being a full-time student. Bivariate and partial correlations are compared to show the extent of change with social-demographic controls.

No substantial change is evident except in the case of educational benefit. After controlling for social demographics, the HECS debt group is no longer more negative about educational benefit than the no-debt group $(r=-.07$, ns).

On other results in Table 2, bivariate and partial correlations are similar. No statistically significant relationship emerged between having a HECS debt and the overall value placed on HECS ( $r=-.09$, ns). Those with a HECS debt remained significantly more likely to see HECS rules as unfair $(r=.26, p<.001)$ and to have weaker feelings of shame over not paying the debt $(r=-.11, p<.05)$ as well as weaker responsibility to pay $(r=-.18, p<.001)$. The debt group also remained more fearful of getting caught for not paying the loan $(r=.13, p<.01)$.

In sum, neither the debt nor the no-debt groups, nor the sample as a whole exhibited such extreme defiance that it could be argued that opposition to HECS was about dismantling the scheme. At the same time, being non-compliant by not paying the debt was not deeply shameful, especially so for those with a debt.

While exploring this further, we noted high correlations among the attitude and belief scales that suggested there were coherent narratives around HECS. For instance, responsibility to pay HECS correlated highly with seeing value in HECS $(r=.64, p<.001)$ and feeling shame if caught for not repaying the debt $(r=.45, p<.001)$. Perception of unfairness in HECS rules was correlated with low regard for the value of HECS $(r=-.56, p<.001)$ and lower likelihood of feeling shame $(r=-.18, p<.001)$. This pattern of high and consistent intercorrelations justified searching the qualitative findings to interrogate more deeply misgivings around HECS. 


\subsection{Qualitative data}

\subsubsection{Benefits}

The qualitative data shed light on what benefits meant for this sample. Firstly, respondents identified the personal benefit of financial help: "Without the opportunity to defer my payment I would not have been able to get the education that I now have." At the same time, many were upset by the "daunting" cost of university and how a "HECS debt took the shine off" getting a degree. Explicit mention of HECS burden was also present: "[It] completely demoralises you ... feel as though [I] can't get ahead until debt is cleared". Others reported "peace of mind" upon repayment: "I am very pleased to have rid myself of the HECS debt, but also feel very grateful to have been able to avail myself [of it]". Others commented on the benefit of not having to take out a loan: "I do enjoy not having a large HECS debt." Some echoed sentiments of previous studies into HECS: "The HECs debt meant we took longer to pay off our home. We had to wait longer to start our family which meant our having less children. At times it has caused financial stress."

Doubts about benefit emerged in the qualitative data through references to "cashstrapped poor-quality education": "My experience is HECS goes up and university funding goes down." Reference was made to the "gap" between the cost of the degree versus the benefits obtained: for example, "I went to University to gain employability. This is not happening!", describing their education as "very second rate compared to the amount it costs". The idea of "making university value for money" was raised: "Fund higher education more so [that] there is a reduced gap between perceived cost of education (HECS) and negative education lifestyle (poor libraries, overcrowded classes)." Many raised questions about where their fees and HECS repayments were going: "Allocate [HECS] repayments straight back into universities not into consolidated revenue" was shared as a recommendation. Others who were supporters of HECS lay blame for student discontent at the feet of government: "Budget cuts and reallocation of finances [that] is reducing the quality of their education".

Respondents were divided when considering the societal benefits of HECS. The importance of tertiary education was widely acknowledged: "Education is the foundation of successful and progressive societies and it is of the utmost importance that it is widely available." Respondents supported the view that "[HECS] was far preferable to up-front fees," a policy which was broadly feared: "We are obviously in the process of moving from completely free degrees a few decades ago to completely up-front paid, full-fee degrees in the future, with the HECS system meant to soften the transition."

But respondents disagreed on whether HECS was the best way of funding tertiary education. Resignation was evident in the responses of some: "I don't like HECS, but feel that in the absence of the political will to make education (from childcare to tertiary) a priority, it works." Others were sceptical and feared compromising learning and skill development: "It discourages an ethic of learning within the nation ..." and "puts pressure on Universities to 'sell' their courses, possibly to the detriment of academic standards."

Consideration of fairness and benefits came together under an ideological umbrella of being pro- or anti-HECS: At one extreme, "get rid of user pays - education is a right;" and "revert to a free higher education system for all (who qualify in terms of academic standards) ... individuals who put the effort into gaining an education contribute a lot 
more to the wealth of the nation." One of the more common calls was to "abolish HECS," sometimes adding "people with a higher education generally pay more tax anyway."

At the opposite end of the political spectrum were those who supported a user pays system: "Educate people to accept the user pays principle which is applied to everything that we do in society, otherwise the taxation burden affects people unfairly;" and "I feel you should pay for something that you derive benefit from. In other words, user pays."

In sum, on the benefits of having a HECS scheme, differences in the sample seemed to be driven more by political leanings than by whether or not one was carrying a HECS debt. On the other hand, both those with a debt and those without questioned whether the government was investing fees back into the universities and both recognised that those with a HECS debt could be struggling.

\subsubsection{Fairness}

Many examples of fairness as an issue emerged regardless of whether one was generally pro- or anti-HECS. Of particular importance were comments about the unfair nature of specific aspects of HECS.

Too low a threshold for loan repayment was a shared concern: "I felt that having to pay back HECS at this income was entirely unfair and contributed to financial hardship;" and "repayments begin at too low a level. It is unfair to force repayments by people earning what are generally considered low wages".

The discounting arrangements for early payment also attracted much criticism on fairness grounds: "It does seem unfair that these people who can afford to pay HECS upfront are allowed a $25 \%$ discount. This favours rich people, and gives them a break."

The differentiation of courses into different fee bands also elicited criticism: "I do not believe it is fair to require students to pay higher HECS fees for some degrees above others." There were calls for government to "abolish the current differential HECS, if HECS is to be differentiated, do it on a basis of what courses actually cost (in terms of resources) NOT on the basis of ... expected future income (most people studying Law do not become lawyers)".

Another commonly aired argument was that "courses should be of the same value medicine, law, veterinary science should not be more expensive as [it] discourages less well-off [students] from studying these disciplines;" and "A knowledge nation = education. A more progressive HECS system [would] encourage people to study law, medicine, science, IT, engineering. ... Your current differential system is moving further from this goal, not towards it."

Administrative changes and failures of communication came in for substantial criticism, with a pervasive sense of a lack of procedural justice in providing debtors with clear, timely and accurate information: "It's very confusing to figure out exactly how much I now owe. I feel very in the dark. It is difficult to contact the HECS people and to get questions answered clearly and easily"; and "I always seem to have to pay extra when all I have is my income, the tax I pay on that, and my HECS debt - how hard can it be?" According to another, "I had not paid enough; I felt bitter about the shortfall". Others summed up the problems this way: "The system needs to communicate with its users."

Constant changes to HECS were experienced also as unfair: "In 1989 I signed up for a loan which was to be paid off when my income reached an 'above average' level, at rates which were in the range $1-3 \%$ of income. That these conditions were subsequently 
changed dramatically (once I had already incurred that debt) does not seem just and has resulted in a system which is much less easy to defend." Another responded, on "changing rates I feel cheated ... UNFAIR.”

Across groups and socioeconomic status, respondents were worried that HECS was disproportionately imposing a financial burden on poorer students: "The HECS scheme promotes inequity between the rich and the poor. The rich don't need HECS and if they use it, they can pay it off quickly;" and "the deferred payment option is the only choice for people who can't afford to pay up-front. This puts these people behind from the beginning." Another respondent who was sympathetic to HECS said: "Look, HECS is a great idea in its basic theory but it is now being used as a revenue raiser that hardest hits the financially disadvantaged without genuine return to the overall level of educational development in Australia!" In the words of another pro-HECS respondent: "I think some form of [HECS] is necessary and it will never please everyone, however the scheme does tend to favour those financially better off."

As the conditions of HECS changed, concern about the effects on students from poorer backgrounds grew: "I used to believe that HECS was a good way of enabling individuals to make a partial contribution towards the cost of their education (appropriate because that education benefits the individual and the society) without discrimination between those who can easily afford to pay and those who cannot. I believe the current system is not so easily accessible to people with limited financial resources, and that repayment rates for those on (relatively) low incomes are now too high."

\subsubsection{Moral obligation}

Despite much criticism of HECS, the qualitative responses displayed notable intolerance of those who were avoiding repaying their debt, evidenced by such comments as: "Stop the cheats;" "ensure people repay their HECS debt;" and "crack down on tax and HECS cheats and frauds and make an example of them."

Avoiding repaying debt was seen as a fairness issue: "The system is unfair because heaps of students just don't bother to pay;" and "there should be greater checks on HECS repayments ... People cheating puts the system in jeopardy." Some were critical of "incentives to avoid" such as the practice at the time of working overseas.

Calls were made for better communication and simplification to address failure to repay: "I think that people should be made aware about the different options of HECs payments and the punishments for not paying a debt;" and "make it simpler and clearer, it is open to cheats, yet confuses the majority."

Others favoured increasing compliance through addressing injustice: "Make the debt fairer and lighter and people will be less resentful and uncooperative about carrying it;" and "just keeping the system fair and transparent will contribute to compliance."

The dominant view was summed up by one respondent who explicitly stated: "I don't believe in breaking the law." Yet there was evidence of chinks in resolve: "I think it is reasonable that HECS is deducted from income. But it shouldn't have to be paid back until income is 30,000 AUD When I earned less than this I really wanted to avoid paying HECS."

One respondent voiced a challenge to paying HECS: “[Your questionnaire] didn't deal with the issue of evasion on principles of ideology. Many people believe that the cost of 
education should be borne by all of society through a progressive tax system. Raise taxes as a whole and make education more free and accessible!"

\section{Discussion}

Our purpose has been to understand more deeply the public disquiet around Australia's income-contingent loan policy for tertiary students despite enthusiasm from policymakers internationally (Britton, van der Erve, and Higgins 2019). The qualitative and quantitative data converge on the centrality of perceptions of fairness. People's perceptions of fairness are at odds with the perceptions of policymakers. This difference is important to understand because how people judge HECS policy determines how willing they are to cooperate with government and comply with rules and expectations. Attitudes held by HECS debtors and to a lesser extent their debt-free peers around the unfairness of HECS rules, under-resourcing of universities and low moral obligation to pay reduces the capacity to administer income-contingent loans effectively. Moreover, perceived injustice that is not addressed places at risk cooperation with other government policies (Nadler 2005).

Fairness, as Wenzel (2003) has argued, is a complex social construction because perceptions of fairness change with social identity. When a person enters the role of citizen and looks at HECS through a national lens, the fairness debate is about what is good for society. The qualitative data provided evidence of the pro-HECS and anti-HECS thinking of graduates. Support for HECS was embedded in the acceptance of a user pays system. Opposition to HECS rested on a belief that education should be freely available to anyone who qualified academically, because those with degrees would pay society back through contributing to the nation's productivity and paying more tax in a progressive tax system.

On the issue of HECS as a societal good, the sample was divided. Nevertheless, the qualitative data revealed common ground between what might be seen as opposing camps. Through the societal fairness lens, there was widespread agreement that more opportunities for higher education should be made available and this was in the national interest. There was also widespread agreement that income from fees should be used to support the quality of universities and that this was not happening. Respondents believed that economically disadvantaged students should not be punished by the HECS system and that this was happening to an increasing degree. Finally, the concern that future students might carry a greater share of responsibility for paying for their university education was expressed by HECS supporters and opponents alike.

As disadvantaged students came into consideration, the frame for fairness moves from national interest to student interest. The role of student had been shared by those who paid fees upfront and those who had a HECS debt. Traditionally, the shared social identity of "student" is seen as one of privilege because it signifies talent and opportunity. But within the role of student, there was consciousness that some were sacrificing basic requirements more than others. The incongruence of economic disadvantage within a meritocratic educational system appears to have triggered perceptions of unfairness around how HECS was operating.

Payment of HECS debts and knowledge of such debts was administered through the tax system. For policymakers this was efficient. For those with a HECS debt, taxpaying 
became imbued with their HECS-related grievances. Those with a HECS debt expressed weaker commitment to acting responsibly to repay HECS debts through the tax system. They also expressed greater fear of deterrence in the event that the tax office caught them for not repaying the debt. This greater fear did not translate into shame, however, as HECS debtors expressed less shame.

Thus, different social identities (citizen, graduate, student, taxpayer) trigger different sets of perceptions of unfairness. Yet as shown by the correlations between the attitude scales, these perceptions did not sit in isolation. Narratives of unfairness had anchors and interconnections in individual belief systems, they were adopted by those with and without HECS debt, and they have had decades to settle into public discourse.

How well do these findings translate to other graduates, do they persist across time, and more importantly across generations of students? Recent parliamentary inquiries reveal that disquiet persists. Furthermore, the results discussed here are consistent with the findings of other studies that have looked at income-contingent loans from the perspective of students and their families across the programme's 30-year history.

That said, the research has clear limitations that should be acknowledged. Sampling of two universities in one territory does not provide evidence of what is happening in the rest of the country. Sampling attitudes at one point of time with a policy that has been so regularly changed also signals the need for caution in the interpretation of findings. With this in mind, the message can be honed back to a simpler proposition: What individuals think is fair matters for how they engage with policy, even more so when they share views of unfairness with those with whom they identify and are socially connected.

Arguably the most serious caveat in this study is an analysis of a more fundamental and critical concept that underpins citizen doubts about benefits, fairness and moral obligation - mistrust in government. In the qualitative data, reference was made to future government intention to shift the cost of tertiary education to students. No measures were included in the questionnaire on trust in government. But it may be mistrust that continues to fuel disquiet and protestation for consecutive changes to the scheme. This is an important issue for future study.

\section{Conclusion}

This paper contributes to this volume through demonstrating that the challenge of better understanding the life circumstances of different social groups who are subject to government public policy is both an objective and subjective exercise: Objective in the sense of knowing the economic and social conditions in which different groups live, subjective in the sense of understanding the psychological meaning they attach to policy and its effect on their lives.

By using the case of Australia's higher education loan scheme, we show that fairness has different meanings for a policymaker, a citizen, a graduate, a student and a taxpayer. Policymakers argue the fairness of the scheme for Australians as a whole from a user-pays frame: those who gain the benefits of a higher education should pay, not taxpayers who take other pathways. Those who have attended university and share the identity of graduate accept that they have benefitted, but see unfairness in the way in which their fees and loan payments are not invested back into higher education to improve its 
quality. As a group, they see themselves as contributors to society and so there is unfairness in imposing too great a financial burden on current and future generations of students. Debtors who pay their debt through the taxation system share this view, but also see unfairness when they compare their lives with those of their peers who are able to pay their fees upfront. In a meritocratic institution like a university, unfairness is fuelled by seeing some students struggle with the basics of living while others do not, and some graduates struggle with payment of loans, while others are debt-free.

Related to seeing the rules of the loan scheme as unfair, which debtors particularly considered to be the case, is a weaker moral obligation to repay the loans. While not paying the loans was criticised widely by the sample, with recommendations for negative sanctions, caveats for when and why you might avoid paying were openly expressed. As countries that have adopted similar income-contingent loans grapple with the problem of doubtful debt (debt that is unlikely to be repaid), they would be advised to attend not only to the economics of repayment but also to the issue of how debtors interpret the fairness of loan conditions at various points in the life cycle.

In pursuing the goal of uncovering different understandings of fairness among graduates, the paper illustrates the value of combining quantitative and qualitative methodologies to better understand the sense-making that social groups undertake when exposed to policies that impose obligations while offering benefits. The narratives that the social groups of graduates who took part in this study developed around unfairness were coherent and appear to be enduring to the present day. They arouse angst around policy implementation and erode cooperation on which democratic states and their tax authorities rely (Braithwaite 2009). Once settled in the public consciousness, the narratives seem difficult to reverse.

\section{Notes}

1. The proportion contributed by students varies between different degrees and across different iterations of the program, with an average of about $40 \%$, according to a 2017 Australian Broadcasting Commission Factcheck. (https://www.abc.net.au/news/2017-06-14/fact-check -do-taxpayers-subsid)

2. HECS-HELP (Higher Education Loans Programme) and FEE-HELP

3. VET FEE-HELP initially, now VET Student Loan

4. https://www.ato.gov.au/Rates/HELP,-TSL-and-SFSS-repayment-thresholds-and-rates $/($ accessed 19/11/2019)

5. https://www.education.gov.au/higher-education-0 (accessed 19/11/2019)

6. The initial discount for upfront fee payment of $15 \%$ was increased in 1993 to $25 \%$. In 1995 a voluntary repayment bonus was introduced to encourage quicker loan repayment.

7. See http://ctsi.org.au/research/hecs.html for project description, questionnaire and descriptive data

\section{Disclosure statement}

No potential conflict of interest was reported by the authors. 


\section{ORCID}

Deborah Cleland (D) http://orcid.org/0000-0001-5015-3054

\section{References}

Ahmed, E. 2005. "Preliminary Findings from the Graduates' Hopes, Visions and Actions (GHVA) Survey." Centre for Tax System Integrity Working Paper 66. Canberra: Australian National University.

Ahmed, E., and V. Braithwaite. 2004. "When Tax Collectors Become Collectors for Child Support and Student Loans: Jeopardizing the Revenue Base?" Kyklos 57 (3): 303-326. doi: 10.1111/ j.0023-5962.2004.00256.x.

Ahmed, E., and V. Braithwaite. 2005. "A Need for Emotionally Intelligent Policy: Linking Tax Evasion with Higher Education Funding." Legal and Criminological Psychology 10 (2): 291-308. doi: 10.1348/135532505X37263.

Australian Government. 2016. "Higher Education Funding Act 1988." https://www.legislation.gov. au/Details/C2016C00171

Barr, N. 2012. "The Higher Education White Paper: The Good, the Bad, the Unspeakable-and the Next White Paper." Journal of Social Policy Administration 46 (5): 483-508. doi: 10.1111/j.14679515.2012.00852.x.

Belfield, C., J. Britton, L. Dearden, and L. van der Erve. 2017. "Higher Education Funding in England: Past, Present and Options for the Future." IFS Briefing Note BN211. UK: Institute of Fiscal Studies.

Birch, E. R., and P. W. Miller. 2006. "HECS and HECS-HELP: Equity Issues.” Journal of Higher Education Policy and Management 28 (2): 97-119. doi: 10.1080/13600800600750921.

Braithwaite, J., and T. Makkai. 1991. "Testing an Expected Utility Model of Corporate Deterrence." Law \& Society Review 25: 7-40. doi: 10.2307/3053888.

Braithwaite, V. 2009. Defiance in Taxation and Governance: Resisting and Dismissing Authority in a Democracy. Cheltenham: Edward Elgar.

Braithwaite, V. 2017. "Closing the Gap between Regulation and the Community." In Regulatory Theory: Foundations and Applications, edited by P. Drahos, 25-41. Canberra: ANU E-press.

Britton, J., L. van der Erve, and T. Higgins (2019) "Income Contingent Student Loan Design: Lessons from around the World.” Economics of Education Review 71: 65-82. doi: 10.1016/j. econedurev.2018.06.001.

Chapman, B. 2006. Government Managing Risk: Income Contingent Loans for Social and Economic Progress. London and New York: Routledge.

Chapman, B., and A. Leigh. 2009. "Do Very High Tax Rates Induce Bunching? Implications for the Design of Income-contingent Loan Schemes.” Economic Record 85(270): 276-289. doi: 10.1111/ j.1475-4932.2009.00554.x.

Clifton, J., D. Díaz-Fuentes, and M. Fernández-Gutiérrez. 2017. "Vulnerable Consumers and Satisfaction with Public Services: Does Country Matter?" International Review of Administrative Sciences 85 (2): 264-285 doi: 10.1177/0020852317691341.

Clifton, J., M. Fernández-Gutiérrez, and M. García-Olalla. 2017. "Including Vulnerable Groups in Financial Services: Insights from Consumer Satisfaction.” Journal of Economic Policy Reform 20 (3): 214-237. doi: 10.1080/17487870.2017.1308866.

Doyle, L. 2013. “And Then There Were None: HECS Discounts." Parliament of Australia. Accessed 25 August 2017. http://www.aph.gov.au/About_Parliament/Parliamentary_ Departments/Parliamentary_Library/FlagPost/2013/April/And_then_there_were_none_ HECS_discounts

Ey, C. 2017. "Higher Education Loan Program (HELP) and Other Student Loans: A Quick Guide." Parliament of Australia. Accessed 25 August 2017. https://www.aph.gov.au/About_Parliament/ Parliamentary_Departments/Parliamentary_Library/pubs/rp/rp1617/Quick_Guides/HELP 
Highfield, R., and N. Warren. 2015. "Does the Australian Higher Education Loan Program (HELP) Undermine Personal Income Tax Integrity?” eJournal of Tax Research 13(1): 202-261.

Jackson, K. 2003a. "The Higher Education Contribution Scheme E-Brief.” Parliament of Australia. Accessed 25 August 2017. http://www.aph.gov.au/About_Parliament/Parliamentary_ Departments/Parliamentary_Library/Publications_Archive/archive/hecs\#Majorchange

Jackson, K. 2003b. "Higher Education Funding Policy." Parliament of Australia. Accessed 25 August 2017. https://www.aph.gov.au/About_Parliament/Parliamentary_Departments/ Parliamentary_Library/Publications_Archive/archive/hefunding

James, R., E. Bexley, M. Devlin, and S. Marginson. 2007. Australian University Student Finances 2006: Final Report of a National Survey of Students in Public Universities. Canberra: Australian Vice-Chancellors' Committee.

Marks, G. 2009. "The Social Effects of the Australian Higher Education Contribution Scheme (HECS)." Higher Education 57 (1): 71-84. doi: 10.1007/s10734-008-9133-5.

Nadler, J. 2005. "Flouting the Law" Texas Law Review 83: 1399-1441

Senate Education and Employment Legislation Committee. 2014. "Submissions to Higher Education and Research Reform Amendment Bill 2014 Inquiry.” Accessed 30 January 2019. http://www.aph.gov.au/Parliamentary_Business/Committees/Senate/Education_and_ Employment/Higher_Education

Senate Education and Employment Legislation Committee. 2017. "Inquiry into the Higher Education Support Legislation Amendment (A More Sustainable, Responsive and Transparent Higher Education System) Bill 2017." Australian Parliament House. Accessed 30 January 2019. http://www.aph.gov.au/Parliamentary_Business/Committees/Senate/Education_ and_Employment/HigherEducation 2017

Tyler, T. R., and S. L. Blader. 2000. Cooperation in Groups: Procedural Justice, Social Identity, and Behavioral Engagement. Philadelphia, PA: Psychology Press.

Wenzel, M. 2003. “Tax Compliance and the Psychology of Justice: Mapping the Field.” In Taxing Democracy: Understanding Tax Avoidance and Evasion, edited by V. Braithwaite, 41-69. Aldershot, UK: Ashgate.

Wran Report. 1988. Report of the Committee on Higher Education Funding. Canberra: Australian Government Publishing Service. 